Stefan PANOVSKI

UDK: 930.1(38)

Original research paper

\title{
THE BANEFUL ADVICE OF AGELAOS
}

\begin{abstract}
In the famed speech delivered during the negotiations in Naupaktos, Agelaos among other things advises Philip $V$ to turn his attention towards the West and the struggle between Rome and Carthage. The similarities with the advice that Demetrios of Pharos previously gave the king is a reason to doubt its authenticity. That the advice is ascribed to an Aitolian should not be taken as an argument in favour of its authenticity, but quite the contrary fits in with Polybios' generally negative image of the Aitolians in this period. Although its authenticity can not be proved with certainty, at least in historical context that may not be too important, for the future actions of Philip $V$ show that it had little impact on the decision for concluding the Peace of Naupaktos.
\end{abstract}

Keywords: POLYBIOS, AGELAOS, DEMETRIOS OF PHAROS, PEACE OF NAUPAKTOS

After three years of fighting, the Social War between the Symmachy led by Philip V and the Aitolian koinon ended with the peace of Naupaktos in august 217 BC. ${ }^{1}$ Since both sides desired peace, the agreement was reached fast and without serious difficulties, which is why Polybios does not give a detailed description of the whole process. According to him, the only thing worth mentioning was the speech that Agelaos, one of the Aitolian leaders, delivered on this occasion:

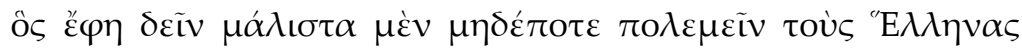

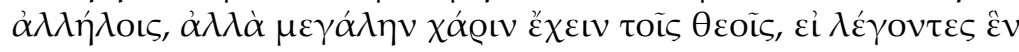

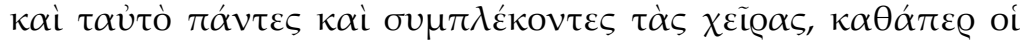

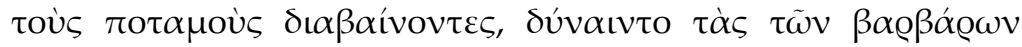
غ̇

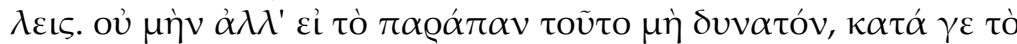

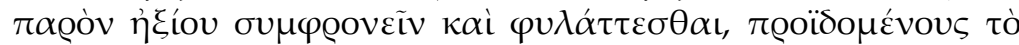

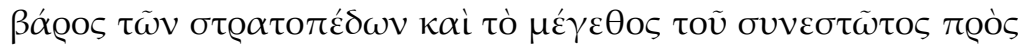

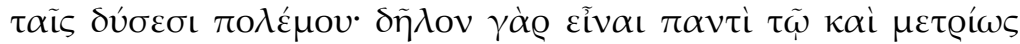

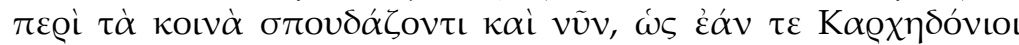

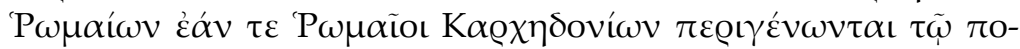

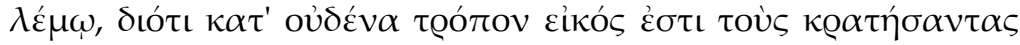

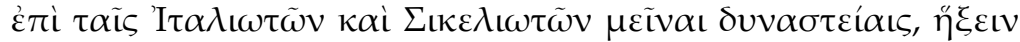

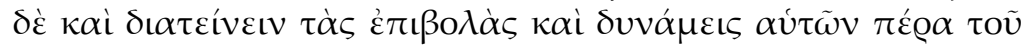

${ }^{1}$ Walbank (1957), 629. 


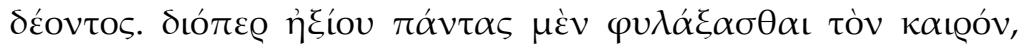

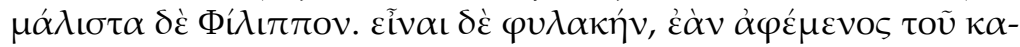

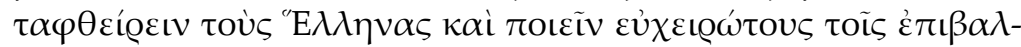

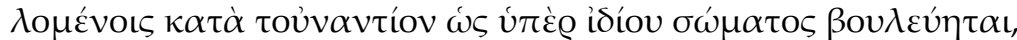

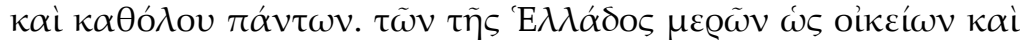

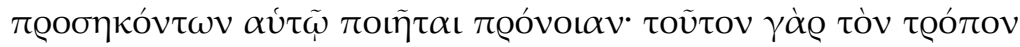

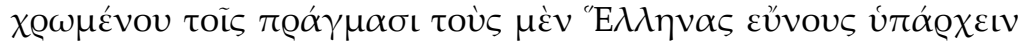

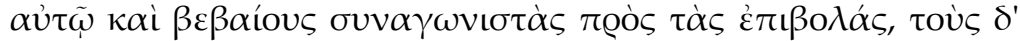

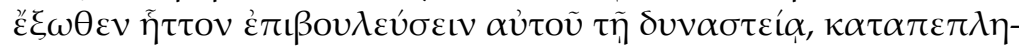

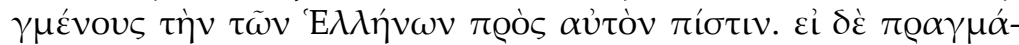

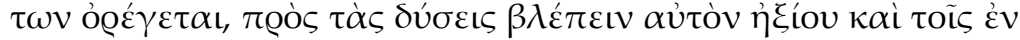

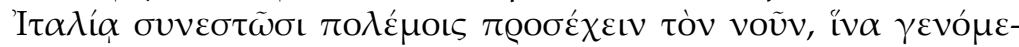

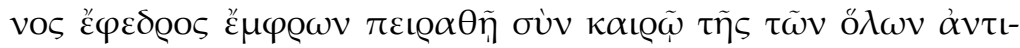

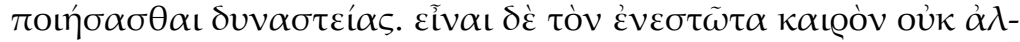

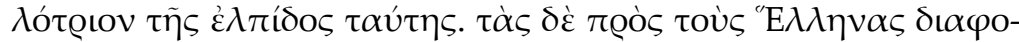

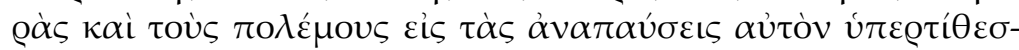

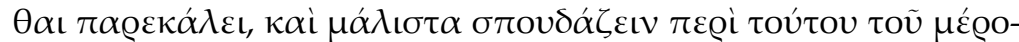

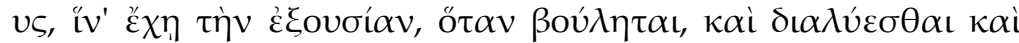

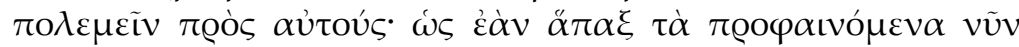

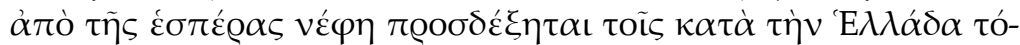

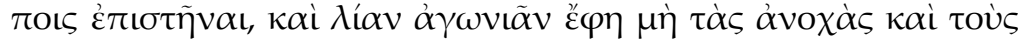

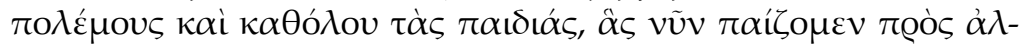

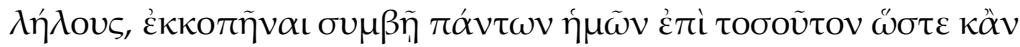

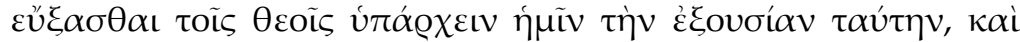

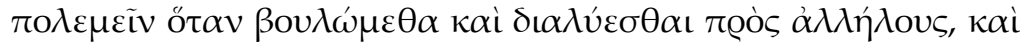

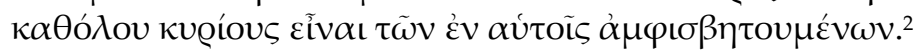

Although there is no agreement among the historians concerning the authenticity of this speech, ${ }^{3}$ I will not go into that question, especially since some important aspects can now be taken as resolved. ${ }^{4}$ Not only is the speech abbreviated and condensed, ${ }^{5}$ but the fact that it matches with the general scheme in which Polybios conveys the speeches, ${ }^{6}$ unambiguously points to authorial interventions by the historiographer. Furthermore, some elements such as the symploke-motif that is such a distinctive and important part of the $\mathrm{Hi}$ stories, are undoubtedly a product of Polybios himself; 7 which does not mean however that the whole speech should be attributed to the Achaian historiographer. In this instance I will confine myself only to the question concerning the

\footnotetext{
2 Polyb., 5.104.

${ }^{3}$ Pédech (1964), passim.; Mørkholm (1967); Id. (1974); Walbank (1972), 69 n.11; Deininger (1973).

${ }^{4}$ Champion (1997); Id. (2000).

${ }^{5}$ Pédech (1964), 264.

${ }^{6}$ Usher (2009), 493-4.

${ }^{7}$ Nikolai (2018), 118.
} 
historicity of the advice that Philip should turn his attention to the West and carefully follow the events in Italy.

1. Because of this speech, Agelaos is often seen as an example of an astute politician who almost predicted the future 8 ; which in turn is being used as one of the main arguments in favor of the authenticity of the speech. Were it work of Polybios, he never would have ascribed it to one of the hated Aitolians. ${ }^{9}$ I am not entirely convinced that Agelaos and his speech are deserving of the reputation and praise they have. The speech contains a number of literary topoi and old political slogans and in fact does not contain as many novelties as it may seem on first look - the call for Greek unity is as old as the Persian war and is a common subject in the political speeches since the late 5th and 4th century; ${ }^{10}$ the advice that Philip should treat the Greeks with benevolence, and defend them as if they were part of his realm sounds like a distant echo of Isokrates' Letter to Philip; even the famed metaphor for the "cloud of war" originates from the Iliad. ${ }^{11}$ As a matter of fact, the counsel regarding Greece is just as utopian as the one of Isokrates, and Agelaos offers no practical advice as to how Philip could accomplish this. As for the "cloud from the west", as Deininger pointed out, there is nothing particularly striking - anyone who paid any attention to what was going on must have been concerned by the prospect of either Rome or Carthage mastering the whole of the western Mediterranean.12 It seems that already Timaios of Tauromenion, one of Polybios' favorite "victims", recognized the importance and danger for the western Greeks that was coming from Rome. ${ }^{13}$ How justified this fear was is another matter, and depends on how we interpret the Roman policy of the period, but that is a question that does not concern us in this instance. If there is anything prophetic in the speech, it is rather an example of a self-fulfilling prophecy - if not for the advice of Demetrios and Agelaos who, according to Polybios, persuaded Philip to turn to the West, it is debatable when and under what circumstances the Romans would have intervened in the Balkans.

This is precisely what leads us to the heart of the matter, and the possible answer as to why an Aitolian. The key is not in the speech itself, but rather in what follows: 'O $\mu \dot{v} v$ oũv A A

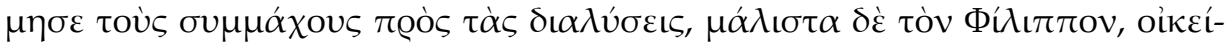

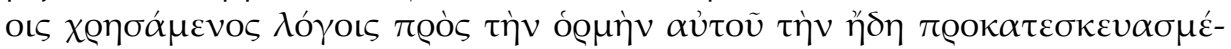

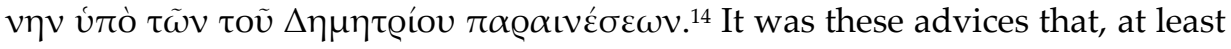

\footnotetext{
8 e.g. Mørkholm (1967), 253: „,a great and prophetic political figure“.

9 Tarn (1928), 768; Walbank (1972), 69 n.11; Deininger (1973), 107. Mørkholm's attempt to answer this objection is not convincing (Mørkholm (1967), 253).

${ }^{10}$ Quite a few interesting comparisons can be drawn with the Lysias' Olympic oration (especially 33.6 and 33.8).

11 v. Usher (2009), 494 n.8.

${ }^{12}$ Deininger (1973), 105.

${ }_{13}$ Walbank (2002), 172-177.

14 Polyb., 5.105.1.
} 
according to Polybios, pushed Philip in one reckless adventure that will culminate with the destruction of Macedon, and essentially, even if not formally, the end of the Greek independence. For anyone familiar with Polybios the irony will not go unnoticed - even though it was an Aitolian who first pointed out the danger from the West, only a few years later the same Aitolians will be the first to form an alliance with Rome against Philip and the Symmachy, ${ }^{15}$ for which they will be criticized by the other Greeks. ${ }^{16}$ Therefore, at least in this particular context, I am not certain that the speech of Agelaos departs from Polybios' generally negative image of the Aitolian koinon in this period, ${ }^{17}$ which in turn leaves room to raise the question concerning its authenticity.

2. The main cause for doubting its authenticity is the similarity with the advice that Demetrios of Pharos previously gave to Philip. For, when he heard about the Roman defeat at the Trasimene, Philip shared the news only with Demetrios who tried to persuade him to end the war in Greece and turn towards Illyria and Italy:

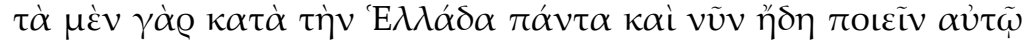

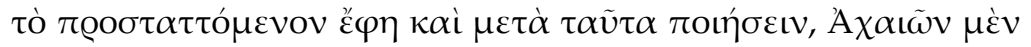

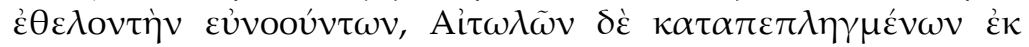

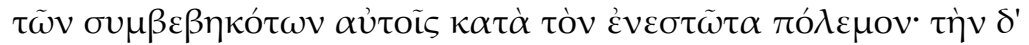

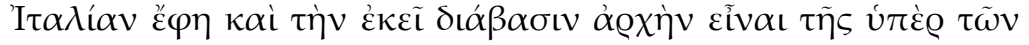

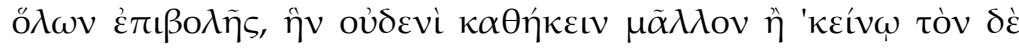

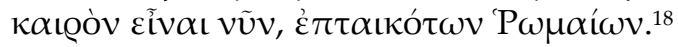

The similarities are obvious, while the differences are a matter of nuances rather than substance - according to Demetrios, though not conquered the Greeks certainly are subdued and Philip should start right away with the conquest of the West; whilst according to Agelaos, Philip should take on the role of a benevolent protector of all the Greeks and sagely wait for the right opportunity to begin the conquest of the West. ${ }^{19}$ For those that deny the authenticity of the speech, this is just another indication that Polybios is the author of both speeches, especially since the conversation between Philip and Demetrios was behind closed doors and Polybios could not have known what was said on that occasion. ${ }^{20}$ On the other hand, two solutions have been offered in defence of its authenticity - the similarities stem from the scheming of Demetrios who, in or-

\footnotetext{
15 Staatsv. III.536.

${ }_{16}$ Polyb., 9.37.5-6; 11.5 .

17 A balanced and persuasive analysis of Polybios' attitude towards the Aitolians in Champion (2007), with a list of relevant modern works.

${ }_{18}$ Polyb., 5.101.9-10.

${ }^{19}$ contra Walbank (1984), 481, who thinks that Agelaos advises Philip not to start a war with Rome, but simply to follow closely the events in Italy and be prepared to defend

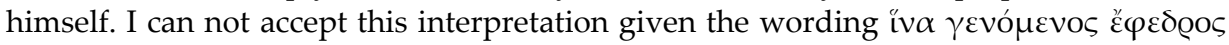

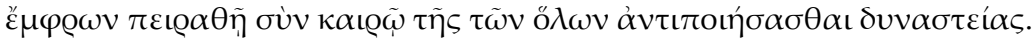

${ }^{20}$ e.g. Hammond (1988), 387.
} 
der for the Aitolians to also persuade Philip in what he was already proposing, before the peace talks perhaps informed them of the king's future plans and intentions; ${ }^{21}$ or that the Aitolians realized what his plans were after the news of the outcome from the battle of Lake Trasimene became widely known, and after the meeting of Philip and his philoi, and the gathering of the allied delegates, where the king advocated for peace which was a volte-face from his previous policy. ${ }^{22}$

Naturally, it is impossible to completely refute such assumptions which are rather based on impressions and hunches. ${ }^{23}$ As for the potential scheme of Demetrios, Champion is certainly correct when he points out that such a move would not be unusual of his character. ${ }^{24}$ Yet, it is questionable whether even he would dare to make such a move that could be qualified as treason, especially in light of the fate of the old associates of Antigonos Doson who perished in a bloody purge the previous year. ${ }^{25}$ Furthermore, as Mørkholm points out, considering the shared interests of Philip and Demetrios the suggestion seems unconvincing. ${ }^{26}$ As for the conjecture that the Aitolians learned or at least sensed the future plans of Philip after his meeting with the king's friends and with the allied delegates afterwards, as Mørkholm rightly points out, just because the allies and friends were informed about his desire for peace, does not mean that he already disclosed his future plans. On the contrary for both political and diplomatic reasons it was important that they be kept a secret, for otherwise the Aitolians might insist on better terms and in doing so could jeopardize or at least delay the peace process. ${ }^{27}$

This whole game of assumptions is largely unproductive and futile. The problem stems from the fact that the discussion is erroneously framed from the very beginning - that Philip desired peace only after learning the about the Roman defeat at Lake Trasimene. This assumption is based on Polybios' analy$\mathrm{sis}^{28}{ }^{28}$ however aside from his personal interpretation he offers no further proof of this. On the contrary, it should not be forgotten that both in 218 and 217 BC Philip gave a positive reply to the offers from the neutral delegates to mediate a peace agreement. ${ }^{29} \mathrm{It}$ is important in this context to stress that in $218 \mathrm{BC}$, although a thirty day truce was agreed upon, the negotiations fell through after

${ }^{21}$ Walbank (1972), 69 n.11; accepted by Champion (1997), 119.

${ }^{22}$ Deininger (1973), 106.

${ }^{23}$ As Walbank himself points out, his suggestion is a hypothesis for which there is no evidence whatsoever (Walbank (1972), 69 n.11).

${ }^{24}$ Champion (1997), 119.

${ }^{25}$ On "the conspiracy of Apelles" v. Errington (1967).

${ }^{26}$ Mørkholm (1974), 128 n.7. The suggestion of Champion that Demetrios hoped that in this way the Aitolians will definitively persuade Philip to turn west, seems to me strange and unconvincing.

${ }^{27}$ Mørkholm (1967), 250-1; Id. (1974), 128-9.

28 Polyb., 5.100.11-101.

${ }^{29}$ Sources and modern works in Ager (1997), no. 53. 
the Aitolians, not Philip, had a change of heart. It should also not be forgotten that Philip never wanted the Social war that originated in the aggressive policy of Aitolia and the policy of Aratos in Messenia. ${ }^{30}$ Even when the war was already in sight, Philip once again sent an offer for negotiations which the Aitolians declined. ${ }^{31}$ Leaving aside these arguments, by $217 \mathrm{BC}$ both sides were so exhausted that there was no prospect of a decisive and complete victory, and therefore Philip had nothing to gain by pursuing the war any longer. ${ }^{32}$ Even if there is an insistence on some correlation between the news of the battle of Lake Trasimene and the Peace of Naupaktos, it should be limited to the potential plans of Philip in Illyria; 33 but even this is debatable. Philip did indeed prepare a fleet of 100 lemboi and in $216 \mathrm{BC}$ moved against Apollonia, but this was a reaction to Skerdilaidas' inroads in Pelagonia and Dassaretis the previous year. ${ }^{34}$

Therefore, there is no need to look for the motives for the end of the war in the events in Italy - both Philip and especially his allies had more than enough reasons to reach a peace agreement. This largely trivializes the issue of the authenticity of the advices by Demetrios and Agelaos, at least taken as a historical problem. Whether authentic or, what seems more probable to me, work of Polybios himself, they were not of decisive importance in reaching the peace agreement in 217 BC. Things stand a bit differently in historiographical context, especially concerning Polybios' attitude towards Macedon, but that question lies outside the scope of this paper. If the above analysis was correct, it just proves once again Walbank's conclusion who showed long ago that when it comes to Macedonia and the policy of the kings, Polybios is often unable to properly assess their goals and motives. ${ }^{35}$

\section{References:}

AGER, S. L. (1997). Interstate arbitrations in the Greek world, 337-90 B.C, Berkeley: University of California Press.

CHAMPION, C. (1997). "The Nature of Authoritative Evidence in Polybius and Agelaus' Speech at Naupactus". TAPA 127, 111-128.

\footnotetext{
30 v. Scholten (2000), 200-212, 275-294; Fine (1940).

${ }^{31}$ Polyb., 4.26.3-6. cf. Scholten (2000), 293-4. contra Walbank 1940, 34; Id. (1957), 474, who thinks that the offer was not sincere but was simply a prewar propaganda. However it is clear from Polybios' narrative that at least the Aitolians thought that Philip was sincere.

32 cf. Errington (2008), 184-5. For the course of the war $v$. Walbank (1940), ch.2; Hammond (1988), 371-91; Scholten (2000), ch.6; Сивкина (2007).

${ }^{33}$ Errington (1990), 189-90.

${ }^{34}$ Polyb., 5.108. pace Champion (1997), 119-20. contra Walbank (1993), 1721-3; Eckstein (2010), 229-30.

${ }^{35}$ Walbank (1970).
} 
CHAMPION, C. (2000). “Romans as BAPBAPOI: Three Polybian Speeches and the Politics of Cultural Indeterminacy". CPh 95.4, 425-444.

Champion, C. (2007). "Polybius and Aetolia: A Historiographical Approach". In J. Marincola (ed.), A companion to Greek and Roman historiography, Malden, MA. \& Oxford: Blackwell Pub., 356-362.

DeININGER, J. (1973). “Bemerkungen zur Historizität der Rede des Agelaos 217 v. Chr. (Polyb. 5,104)". Chiron 3, 103-108.

ECKSTEIN, A. M. (2010). “Macedonia and Rome, 221-146 BC". In J. Roisman \& I. Worthington (eds.), A Companion to Ancient Macedonia. Malden, MA. \& Oxford: Wiley-Blackwell, 225-250.

ERrington, R. M. (1967). "Philip V, Aratus, and the 'Conspiracy of Apelles'”. Historia 16.1, 19-36.

ERrington, R. M. (1990). A History of Macedonia. Berkeley \& Los Angeles: University of California Press.

ERrington, R. M. (2008). A History of the Hellenistic World. Malden, MA: Blackwell Pub.

FINE, J. V. A. (1940). “The Background of the Social War of 220-217 B. C.". AJPh 61.2, 129-65.

Hammond, N. G. L. (1988). N. G. L. Hammond \& F. W. Walbank, A History of Macedonia, vol.III. Oxford: Clarendon Press.

MørKholm, O. (1967). "The Speech of Agelaus at Naupactus, 217 B.C.". CEM 28, 240-53.

MørKholm, O. (1974). “The Speech of Agelaus, Again”. Chiron 4, 127-32.

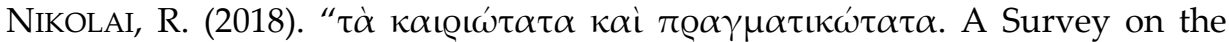
Speeches in Polybius". In N. Miltsios \& M. Tamiolaki (eds.), Polybius and his Legacy. Berlin: de Gruyter, 117-30.

PÉDECH, P. (1964). La méthode historique de Polybe. Paris: Les Belles Lettres.

Scholten, J. B. (2000). The Politics of Plunder: Aitolians and their Koinon in the Early Hellenistic Era 279-217 B.C. Berkeley \& Los Angeles: University of California Press.

Сивкина, Н. Ю. (2007). Последний конфликт в независимой Грециии: Союзническая война 220-217 г2. до н.э. Санкт-Петербург: Издательский Центр «Гуманитарная Академия».

TARN, W. W. (1928). “The Greek Leagues and Macedonia”. Cambridge Ancient History VII. Cambridge: Cambridge Univeristy Press, 732-68.

UsHeR, S. (2009). "Oratio Recta and Oratio Obliqua in Polybius". GRBS 49, 487514.

Walbank, F. W. (1940). Philip V of Macedon. Cambridge: Cambridge University Press.

Walbank, F. W. (1957). A Historical Commentary on Polybius, v.1. Oxford: Oxford University Press. 
Walbank, F. W. (1970). "Polybius and Macedonia". Archaia Makedonia I, 291307.

Walbank, F. W. (1972). Polybius. Berkeley \& Los Angeles: University of California Press.

Walbank, F. W. (1984). “Macedonia and the Greek leagues". Cambridge Ancient History2 VII.1. Cambridge: Cambridge University Press, 446-481.

WAlBANK, F. W. (1993). „H T $\Omega$ N O $\Lambda \Omega N$ E $\Lambda \Pi I \Sigma$ and the Antigonids“, Archaia Makedonia V, 1721-30.

WALBANK, F. W. (2002). “Timaeus' views on the past". In F. W. Walbank (ed.), Polybius, Rome and the Hellenistic World : Essays and Reflections. Cambridge: Cambridge University Press, 165-177. 